\title{
Dietary conjugated linoleic acid mixture affects the activity of intestinal acyl coenzyme A: cholesterol acyltransferase in hamsters
}

\author{
Chi Hang Thomas Yeung ${ }^{1}$, Lin Yang ${ }^{1,3}$, Yu Huang ${ }^{2}$, Jun Wang ${ }^{1}$ and Zhen-Yu Chen ${ }^{1 *}$ \\ ${ }^{1}$ Department of Biochemistry and ${ }^{2}$ Physiology, The Chinese University of Hong Kong, Shatin, \\ New Territories, Hong Kong \\ ${ }^{3}$ Department of Chemistry, Henan Normal University, Xinxiang, Heanan, The People's Republic of China
}

(Received 14 December 1999 - Revised 11 May 2000 - Accepted 23 June 2000)

\begin{abstract}
The present study was designed to study the mechanisms by which dietary conjugated linoleic acids (CLA) decrease serum cholesterol. Hamsters were fed a semi-synthetic diet containing $1 \mathrm{~g}$ cholesterol/kg diet with or without supplementation with $20 \mathrm{~g}$ linoleic acid (LA) and $20 \mathrm{~g}$ CLA/ $\mathrm{kg}$ diet. After 8 weeks, serum fasting total cholesterol (TC) and triacylglycerol (TG) were significantly lower in the LA-supplemented and CLA-supplemented groups compared with those of the control (CTL) hamsters. In contrast to LA, CLA significantly lowered hepatic cholesterol but it increased the level of adipose tissue cholesterol, suggesting that the hypocholesterolaemic mechanism of CLA is different from that of LA. CLA decreased the activity of intestinal acyl CoA:cholesterol acyltransferase (ACAT) whereas LA had no effect on this enzyme. Consequently, CLA supplementation increased the faecal excretion of total neutral sterols, but it had no or little effect on the faecal acidic sterols. If the ACAT is associated with cholesterol absorption, the part of mechanisms by which CLA decreases serum cholesterol may involve down-regulation of intestinal ACAT activity.
\end{abstract}

Cholesterol: Conjugated linoleic acids: Linoleic acid: Triacylglycerol

Conjugated linoleic acids (CLA) refers to a group of positional and geometric isomers of linoleic acid (LA). In contrast to those in LA, the double bonds in CLA are conjugated, instead of being in the typical methylene interrupted configuration. CLA is predominantly found in meat and dairy products (Ha et al. 1989; Chin et al. 1992). Low concentrations of CLA also occur in the lipids of human blood, tissue and milk (Cawood et al. 1983; Iversen et al. 1985). CLA can also be prepared chemically by biohydrogenation (Kepler \& Tove, 1967; Hughes et al. 1982) and by alkali isomerization of LA (Nichols et al. 1951).

High plasma cholesterol has been ranked as one of the greatest risk factors in development of CHD (Neaton et al. 1984; Grundy, 1986). Supplementation with CLA could significantly lower serum total cholesterol (TC), LDLcholesterol and triacylglycerol (TG) in rabbits (Lee et al. 1994) and hamsters (Nicolosi et al. 1997). Thus, the risk factors for atherosclerosis including the LDL-cholesterol:
HDL-cholesterol ratio and the TC:HDL-cholesterol ratio were significantly reduced. However, the hypocholesterolaemic mechanism involved remains poorly understood. We have previously chosen Golden Syrian hamsters (Mesocricetus auratus) to study the potency of green tea catechins (Chan et al. 1999). Golden Syrian hamsters have been increasingly used as a model to estimate the efficacy of hypocholesterolaemic agents in human subjects (Sugiyama et al. 1995). Unlike rats, in which most of the serum cholesterol is in HDL, the major cholesterol carrier in hamsters is LDL as in man (Nistor et al. 1987; Lehmann et al. 1993). There are many similarities between hamsters and man in their intrinsically low rate of hepatic cholesterogenesis, in their response to different diet and drugs, and in the manner in which they handle biliary sterol secretion (Nistor et al. 1987). The present study was designed to test our hypothesis that dietary CLA decreases serum cholesterol, probably by its inhibition on cholesterol absorption, using hamsters as an animal model.

\footnotetext{
Abbreviations: ACAT, acyl CoA:cholesterol acyltransferase; CLA, conjugated linoleic acids; HMG, 3-hydroxy-3-methylglutaryl; LA, linoleic acid; TC, total cholesterol; TG, triacylglycerol.

* Corresponding author: Dr Zhen-Yu Chen, fax +852 2603 5123, email zhenyuchen@cuhk.edu.hk
} 
Table 1. Composition of experimental diets*

\begin{tabular}{lccc}
\hline Content & CTL $(\mathrm{g} / \mathrm{kg})$ & LA $(\mathrm{g} / \mathrm{kg})$ & CLA $(\mathrm{g} / \mathrm{kg})$ \\
\hline Cornstarch & 488 & 478 & 478 \\
Casein & 200 & 200 & 200 \\
Lard & 100 & 100 & 100 \\
Sucrose & 150 & 140 & 140 \\
Mineral mix & 40 & 40 & 40 \\
Vitamin mix & 20 & 20 & 20 \\
DL-Methionine & 1 & 1 & 1 \\
Cholesterol & 1 & 1 & 1 \\
Linoleic acid & - & 20 & - \\
Conjugated linoleic acids & - & - & 20 \\
\hline
\end{tabular}

CTL, control diet; LA, linoleic acid-supplemented diet; CLA, conjugated linoleic acids-supplemented diet.

* For details of preparation of the diets see p. 936.

\section{Materials and methods}

\section{Animals and diet}

The hypercholesterolaemic diet described by Sanders \& Sandaradura (1992) was modified and used in the present study. The control diet was prepared by mixing casein, lard, cornstarch, sucrose, AIN-76 mineral mix, AIN-76A vitamin mix, DL-methionine and cholesterol as shown in Table 1. The ingredients were purchased from Harlan Teklad (Madison, WI, USA) except for lard, which was obtained from the local market, and DL-methionine and cholesterol, which were purchased from Sigma (St Louis, MO, USA). To achieve the high hypolipidaemic activity, CLA (purity $890 \mathrm{~g} / \mathrm{kg}$, Tonalin ${ }^{\mathrm{TM}}$, Natural Lipids Ltd, AS, Hovdebygda, Norway) and LA (Sigma) were added to the diet at a level of $20 \mathrm{~g} / \mathrm{kg}$ diet. The diets $(1 \mathrm{~kg})$ were then mixed with $250 \mathrm{ml}$ gelatin solution $(40 \mathrm{~g} / \mathrm{l})$. Once the gelatin had set, the food was cut into cubed portions of about $20 \mathrm{~g}$ and stored frozen at $-20^{\circ} \mathrm{C}$.

Thirty-six male Syrian Golden hamsters (125-140 g; The Chinese University of Hong Kong, Shatin, Hong Kong) were randomly divided into three groups (n 12 per group) with approximately equal mean group bodyweights. The animals were housed (two hamsters per cage) in an animal room at $23^{\circ} \mathrm{C}$ with a $12 \mathrm{~h}$ light-dark cycle. The hamsters were fed one of the three diets for 8 weeks. Fresh diet was given to the animals daily, and uneaten food was discarded. Food intake was measured daily and body weight was recorded twice per week. The protocol was reviewed and approved by the Committee of Animal Ethics, The Chinese University of Hong Kong. The $4 \mathrm{~d}$ total faecal output was collected during feeding. All hamsters were killed at the end of experiment after food deprivation for $14 \mathrm{~h}$. The blood was collected via the abdominal aorta. After clotting, the blood was centrifuged at $1300 \mathrm{~g}$ for $15 \mathrm{~min}$, and serum was then collected. The liver, peri-renal adipose tissue, kidney, heart, brain and muscle (Adductor longus) were also retained.

At the same time, another thirty hamsters were divided randomly into three groups ( $n 10$ per group) and were similarly maintained on one of the three diets for 8 weeks. The hamsters were then killed without overnight fasting (full stomach). The objective was to enhance the activity of intestinal acyl CoA:cholesterol acyltransferase (ACAT), which is believed to play an important role in esterification before absorption of dietary cholesterol. To be consistent, the first $10 \mathrm{~cm}$ of intestine from the stomach was discarded, and the next $30 \mathrm{~cm}$ was taken for the intestinal ACAT assay (Helgerud et al. 1981; Murakami et al. 1995). All the tissues were stored at $-78^{\circ} \mathrm{C}$.

\section{Analysis of conjugated linoleic acids in the diet}

The pure CLA mixture $(890 \mathrm{~g} / \mathrm{kg}, 3 \mathrm{~kg})$ was obtained as a gift from Natural Lipids Ltd, AS. The CLA from diet was converted to the corresponding fatty acid methyl esters with methanolic hydrogen chloride under $\mathrm{N}_{2}$ at $90^{\circ} \mathrm{C}$ for $45 \mathrm{~min}$. The CLA-fatty acid methyl esters were separated and quantified using capillary GLC method previously described by us (Chen et al. 1997) and $\mathrm{Ag}^{2+}$ HPLC method described by Sehat et al. (1998). In the GLC method, the CLA-methyl esters were separated in a flexible silica capillary column (SP 2560, $100 \mathrm{~m} \times 0.25 \mathrm{~mm}$ internal diameter; Supelco, Inc., Bellefonte, PA, USA) in a HP 5890 Series II GLC equipped with a flame-ionization detector (Hewlett-Packard, Palo Alto, CA, USA). In the $\mathrm{Ag}^{2+}$ HPLC method, the analysis was performed on a $\mathrm{Ag}$ impregnated column $(4.6 \mathrm{~mm}$ internal diameter $\times 250 \mathrm{~mm}$; Chrompack, Bridgewater, NJ, USA) with an Alltech Model 525 HPLC equipped with a ternary pump delivery system and a u.v. detector (Alltech, Deerfield, IL, USA). The fatty acid composition of the three diets is shown in Table 2.

\section{Determination of blood cholesterol}

Enzymatic kits were purchased from Sigma to measure serum TG (catalogue number 336-20) and TC (catalogue number 352-20). HDL-cholesterol was isolated by precipitation of the apolipoprotein B-containing lipoproteins with sodium phosphotungstate-magnesium chloride using the commercial Sigma kit (catalogue number 352-4) as described by Lee et al. (1994) and Nicolosi et al. (1997).

Table 2. Fatty acid composition of diets*

\begin{tabular}{|c|c|c|c|}
\hline Fatty acids & CTL (g/kg) & $\mathrm{LA}(\mathrm{g} / \mathrm{kg})$ & CLA $(\mathrm{g} / \mathrm{kg})$ \\
\hline Myristic & $2 \cdot 05$ & 1.93 & 1.96 \\
\hline Palmitic & 26.65 & 25.99 & $26 \cdot 31$ \\
\hline Palmitoleic & 1.91 & 1.90 & 1.87 \\
\hline Stearic & $15 \cdot 77$ & 15.93 & $16 \cdot 14$ \\
\hline Oleic & 31.94 & 32.46 & 33.00 \\
\hline Vaccenic & 1.86 & 1.85 & 1.87 \\
\hline Linoleic & 9.82 & $29 \cdot 37$ & $10 \cdot 01$ \\
\hline Arachidic & 0.23 & 0.24 & 0.25 \\
\hline Linolenic & 0.46 & 0.48 & 0.47 \\
\hline Others & 4.3 & 4.84 & $5 \cdot 11$ \\
\hline Total CLA & - & - & 17.97 \\
\hline$(\mathrm{t} 10, \mathrm{t} 012)-\mathrm{CLA}$ & - & - & 0.92 \\
\hline (t11,t13)-CLA & - & - & 0.98 \\
\hline$(\mathrm{c} 9, \mathrm{t} 11 / \mathrm{t} 9, \mathrm{c} 11)-\mathrm{CLA}$ & - & - & $7 \cdot 92$ \\
\hline (c10,t12/t10,c12)-CLA & - & - & $7 \cdot 82$ \\
\hline$(\mathrm{c} 9, \mathrm{c} 11)-\mathrm{CLA}$ & - & - & 0.16 \\
\hline (c10,c12)-CLA & - & - & $0 \cdot 17$ \\
\hline
\end{tabular}

CTL, control diet; LA, linoleic acid-supplemented diet; CLA, conjugated linoleic acids-supplemented diet; t, trans; c, cis.

${ }^{*}$ For details of analytic procedures see p. 936. 


\section{Determination of tissue cholesterol}

TC was determined as previously described by Chan et al. (1999). In brief, the total lipids were extracted, and the lipid extracts were then saponified. The non-saponified substances including cholesterol were converted to their trimethylsilyl-ether derivatives and subjected to the GLC analysis in a fused silica capillary column (SAC ${ }^{\mathrm{TM}}-5$, $30 \mathrm{~m} \times 0.25 \mathrm{~mm}$, internal diameter; Supelco, Inc.) using a Shimadzu GC-14 B GLC equipped with a flame ionization detector (Shimadzu, Tokyo, Japan).

\section{Determination of faecal neutral and acidic sterols}

Faecal neutral and acidic sterols were determined as previously described by Chan et al. (1999). In brief, the faecal samples were saponified. The total neutral sterols were extracted using cyclohexane and were then converted to their corresponding trimethylsilyl-ether derivatives for GLC analysis. The remaining aqueous layer was treated with $10 \mathrm{M}-\mathrm{NaOH}$ and $3 \mathrm{M}-\mathrm{HCl}$ followed by twice-repeated extraction with diethyl ether. The acidic sterols were similarly converted to their trimethylsilyl-ether derivatives and subjected to GLC analysis.

\section{Assays of 3-hydroxy-3-methylglutaryl-CoA reductase}

Liver microsomes were isolated according to Erickson et al. (1977). The activity of liver 3-hydroxy-3-methylglutaryl (HMG)-CoA reductase was measured as previously described by Shapiro et al. (1969) and modified by Heller \& Strewsbury (1976).

\section{Acyl CoA:cholesterol acyltransferase assay}

The mucosa microsome was prepared according to the method previously described by Murakami et al. (1995). The ACAT activity was determined essentially using the method developed by Helgerud et al. (1981) with some modifications. Each assay contained $200 \mu \mathrm{g}$ microsomal protein and $200 \mu \mathrm{g}$ fatty acid-free bovine serum albumin in $190 \mu \mathrm{l}$ potassium phosphate buffer $(0.1 \mathrm{M}, \mathrm{pH} 7.4)$ containing $1 \mathrm{mM}$-EDTA. The mixture was incubated at $37^{\circ} \mathrm{C}$ for $6 \mathrm{~min}$ and the reaction was then initiated by adding $5 \mathrm{nmol}\left[1-{ }^{14} \mathrm{C}\right]$ oleoyl-CoA $\left(\mathrm{NEN}^{\mathrm{TM}}\right.$, MA, USA) followed by incubation at $37^{\circ} \mathrm{C}$ for $6 \mathrm{~min}$. The reaction was stopped by adding $5 \mathrm{ml}$ chloroform-methanol $(2: 1$, v/v) and $1 \mathrm{ml} 0.04 \mathrm{M}-\mathrm{HCl}$. To the mixture, $10 \mu \mathrm{l}\left[{ }^{3} \mathrm{H}\right]$ cholesteryl oleate was then added as an internal standard. After the mixture was vortexed and centrifuged, the organic layer was taken and dried under $\mathrm{N}_{2}$ gas. The sample was then dissolved in $50 \mu \mathrm{l}$ chloroform containing $0.1 \mathrm{mg}$ cholesteryl oleate and spotted on a TLC plate $(20 \times 20 \mathrm{~cm}$ plate precoated with $250 \mu \mathrm{m}$ silica gel 60A; Macherey-Nagel, Duren, Germany). The different lipid classes were separated in hexane-diethyl ether-acetic acid (80:20:1, by vol.) and then exposed to I vapour. The band containing cholesteryl oleate was scraped off into scintillation vials, and the radioactivity was counted.
Table 3. Changes in food intake, body-weight gain, and individual organ weights*

(Mean values and standard deviations for twelve hamsters per group)

\begin{tabular}{|c|c|c|c|c|c|c|}
\hline & \multicolumn{2}{|c|}{ CTL } & \multicolumn{2}{|c|}{ LA } & \multicolumn{2}{|c|}{ CLA } \\
\hline & Mean & $\mathrm{SD}$ & Mean & SD & Mean & SD \\
\hline Initial body weight $(\mathrm{g})$ & $120 \cdot 8$ & $7 \cdot 0$ & 121.3 & 8.0 & $120 \cdot 8$ & $7 \cdot 6$ \\
\hline Final body weight $(\mathrm{g})$ & $166 \cdot 7$ & $10 \cdot 5$ & $167 \cdot 5$ & $16 \cdot 7$ & $161 \cdot 3$ & $12 \cdot 3$ \\
\hline Food intake $(\mathrm{g} / \mathrm{d})$ & 14.0 & $2 \cdot 4$ & 14.0 & $2 \cdot 4$ & 13.9 & $2 \cdot 6$ \\
\hline \multicolumn{7}{|l|}{ Organs $(\mathrm{g})$} \\
\hline Liver & 7.57 & 0.73 & 7.74 & 0.60 & $7 \cdot 77$ & 71.14 \\
\hline Peri-renal adipose tissue & $2 \cdot 19$ & 0.82 & $2 \cdot 23$ & 0.69 & 1.83 & $\begin{array}{ll}30.39\end{array}$ \\
\hline Kidney & 0.67 & 0.04 & 0.71 & 0.09 & 0.65 & 50.04 \\
\hline Heart & 0.54 & 0.03 & 0.55 & 0.04 & 0.53 & 30.04 \\
\hline Brain & 0.97 & 0.11 & 0.95 & 0.11 & 0.96 & 0.08 \\
\hline
\end{tabular}

CTL, control diet; LA, linoleic acid-supplemented diet; CLA, conjugated linoleic acids-supplemented diet.

* For details of diets see Table 1, and for procedures see p. 936.

\section{Statistics}

Data are expressed as mean values and standard deviations. ANOVA was used where applicable for statistical evaluation of significant differences among the control, the LAand CLA-supplemented groups using Sigmastat (Jandel Scientific Software, San Rafael, CA, USA). Differences were considered significant when $P<0.05$.

\section{Results}

Body-weight gain, organ weight and food intake

There were no significant differences in food intake and body-weight gain among the three groups throughout the study period (Table 3 ). No differences in organ weights among the three groups were observed.

\section{Effect of conjugated linoleic acids supplementation on serum total cholesterol, HDL-cholesterol and triacylglycerol}

CLA and LA supplementation significantly reduced the fasting serum TC by $10 \%$ and $12 \%$ respectively, when compared with the control $(P<0 \cdot 01$, Table 4$)$. Similarly,

Table 4. Effect of dietary conjugated linoleic acids as a mixture and linoleic acid on serum, liver and adipose tissue lipids*

(Mean values and standard deviations for twelve hamsters per group)

\begin{tabular}{|c|c|c|c|c|c|c|}
\hline & \multicolumn{2}{|c|}{ CTL } & \multicolumn{2}{|c|}{ LA } & \multicolumn{2}{|c|}{ CLA } \\
\hline & Mean & SD & Mean & SD & Mean & SD \\
\hline Serum total cholesterol $(\mathrm{g} / \mathrm{l})$ & $2 \cdot 08^{a}$ & 0.11 & $1 \cdot 84^{b}$ & 0.14 & $1 \cdot 89^{b}$ & 0.14 \\
\hline Serum HDL-cholesterol (g/l) & 1.06 & $0 \cdot 16$ & 0.99 & 0.07 & 1.06 & 0.08 \\
\hline $\begin{array}{l}\text { Serum triacylglycerol }(\mathrm{g} / \mathrm{l}) \\
\text { Cholesterol }\end{array}$ & $3 \cdot 29^{a}$ & 0.32 & $2 \cdot 61^{b}$ & 0.53 & $2 \cdot 22^{b}$ & 0.55 \\
\hline Liver (mg/g) & $20^{a}$ & 3 & $22^{a}$ & 5 & $8^{b}$ & 2 \\
\hline $\begin{array}{l}\text { Perirenal adipose } \\
\text { tissue }(\mathrm{mg} / \mathrm{g})\end{array}$ & $1 \cdot 1^{b}$ & $0 \cdot 1$ & $1 \cdot 1^{b}$ & $0 \cdot 2$ & $1 \cdot 6^{a}$ & $0 \cdot 2$ \\
\hline Adductor longus (mg/g) & $0 \cdot 38^{a}$ & 0.02 & $0 \cdot 34^{b}$ & 0.03 & $0 \cdot 35^{b}$ & 0.02 \\
\hline
\end{tabular}

CTL, control diet; CA, linoleic acid-supplemented diet; CLA, conjugated linoleic acids-supplemented diet.

a,b Mean values within a row with unlike superscript letters were significantly different $(P<0.05)$.

* For details of diets see Table 1, and for procedures see p. 936. 
fasting serum TG was markedly decreased by $34 \%$ and $21 \%$ respectively, in hamsters fed $20 \mathrm{~g}$ CLA and $20 \mathrm{~g} \mathrm{LA} /$ $\mathrm{kg}$ diet in comparison with that in the control group $(P<$ $0 \cdot 01$, Table 4). However, no difference was observed in serum HDL-cholesterol among the three groups (Table 4).

\section{Effect of conjugated linoleic acids supplementation on hepatic cholesterol and triacylglycerol}

As compared with that of the control and LA-supplemented group, the hepatic cholesterol level was significantly lower in CLA-supplemented hamsters (Table 4). However, all three groups had the similar level of hepatic TG.

\section{Effect of conjugated linoleic acids supplementation on levels of cholesterol in other tissues}

Unlike that of liver, the adipose tissue cholesterol level in the CLA-supplemented group was markedly increased by $45 \%$ as compared with the control group $(P<0.01$, Table 4). Significantly lower muscle cholesterol levels in the CLA- and LA-supplemented groups were also observed as compared with that of the control (Table 4). However, no differences in the cholesterol level of brain, heart and kidney were observed (data not shown).

\section{Effect of conjugated linoleic acids supplementation on hepatic 3-hydroxy-3-methylglutaryl-CoA reductase and intestinal acyl CoA:cholesterol acyltransferase}

No differences in hepatic HMG-CoA reductase were observed among the three groups. The HMG-CoA reductase activity for the control, LA and CLA groups was $20.3,20.4$ and $20.7 \mathrm{pmol} / \mathrm{min}$ per $\mathrm{mg}$ protein respectively. However, the intestinal ACAT activity of CLA-supplemented group was reduced by $58 \%(P<0.05)$ as compared with that of control and LA-supplemented hamsters (Fig. 1). There was no difference in the intestinal ACAT activity between the control and LA-supplemented groups.

\section{Effect of conjugated linoleic acids supplementation on faecal neutral and acidic sterols}

The neutral sterols refer to the sum of cholesterol, coprosterol, coprostanone, dihydrocholesterol, campesterol, $\beta$-sisterol and stigmastenol. The total faecal neutral sterols were significantly elevated in the CLA-supplemented groups as compared with the control and LA-supplemented groups (Fig. 2). The acidic sterols measured include lithocholic, deoxycholic, cholic acid and ursodeoxycholic acid (Chan et al. 1999). CLA supplementation did not affect the faecal excretion of acidic sterols as compared with the control and LA-supplemented groups throughout the study period except at day 36 and 44 (Fig. 3).

\section{Discussion}

The present study confirmed that dietary CLA as a mixture possessed a favourable effect on serum lipids by significantly reducing fasting serum TC and TG with no effect on

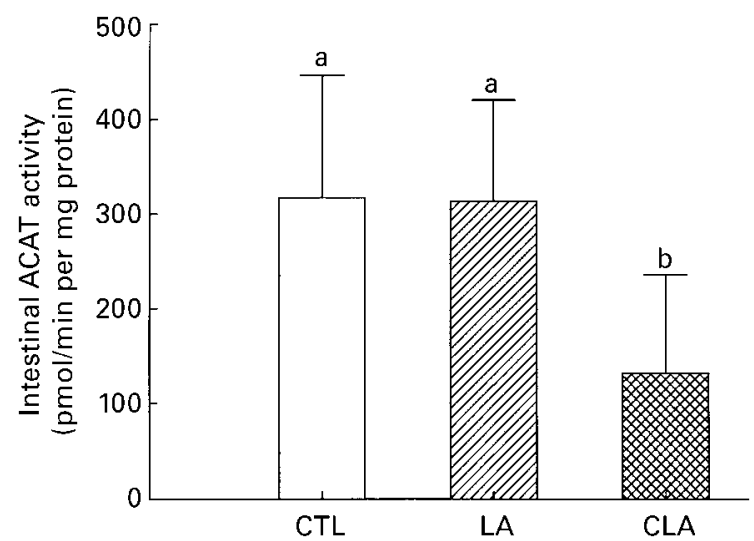

Fig. 1. Effects of conjugated linoleic acids (CLA) and linoleic acid (LA) on intestinal acyl CoA:cholesterol acyltransferase (ACAT) activity in hamsters. CTL, control. $\square$, control; supplemented; $\otimes$ conjugated linoleic acids-supplemented group. For details of the diets see Table 1, and for procedures see p. 936. Values are means for ten hamsters per group with standard deviations represented by vertical bars. ${ }^{a, b}$ Mean values with unlike superscript letters were significantly different $(P<0.05)$.

HDL-cholesterol. Thus, the TC:HDL-cholesterol ratio was significantly decreased. The result is in agreement with that of other studies using rabbits (Lee et al. 1994), mice (Munday et al. 1999) and hamsters (Nicolosi et al. 1997) as animal models. However, the present result is in disagreement with that reported by de Deckere et al. (1999), who found that CLA mixture decreased TC at week 4 but it had no significant effect on TC at week 8 in hamsters fed a diet containing $0 \cdot 1 \mathrm{~g}$ cholesterol $/ \mathrm{kg}$.

The mechanisms by which dietary CLA lowered serum TC remains poorly understood. It is known that a diet higher in LA is associated with lower serum TC compared with a diet higher in saturated fatty acids. It is possible that CLA acts partially like LA. First, CLA, like LA, may occupy more space within lipoprotein particles, resulting in fewer cholesterol ester molecules residing in the core of LDL particles (Spritz \& Mishkel, 1969), provided that CLA isomers significantly accumulate in LDL particle. Second, CLA, like LA, may reduce number of LDL particles by inhibition of hepatic synthesis of apolipoprotein B-containing lipoproteins (Vegas et al. 1982). In fact, it was recently found that trans-10, cis-12-CLA isomer could significantly reduce in vitro apolipoprotein B secretion in HepG2 cells (Yotsumoto et al. 1999). Third, dietary CLA like LA may increase the LDL receptor activity and thus enhance the fractional clearance rate of LDL in circulation (Grundy \& Denke, 1990).

It was also noticed that the mechanism for the cholesterol-lowering effect of dietary CLA, on the other hand, might be different from that of dietary LA. First, dietary CLA decreased not only serum TC, but also liver cholesterol (Table 4) in comparison with LA, which had no effect on hepatic cholesterol level. Second, dietary CLA led to a higher level of adipose tissue cholesterol whereas dietary LA did not influence the level of adipose tissue cholesterol as compared with the control hamsters. We have no explanation for the cholesterol-raising effect of 


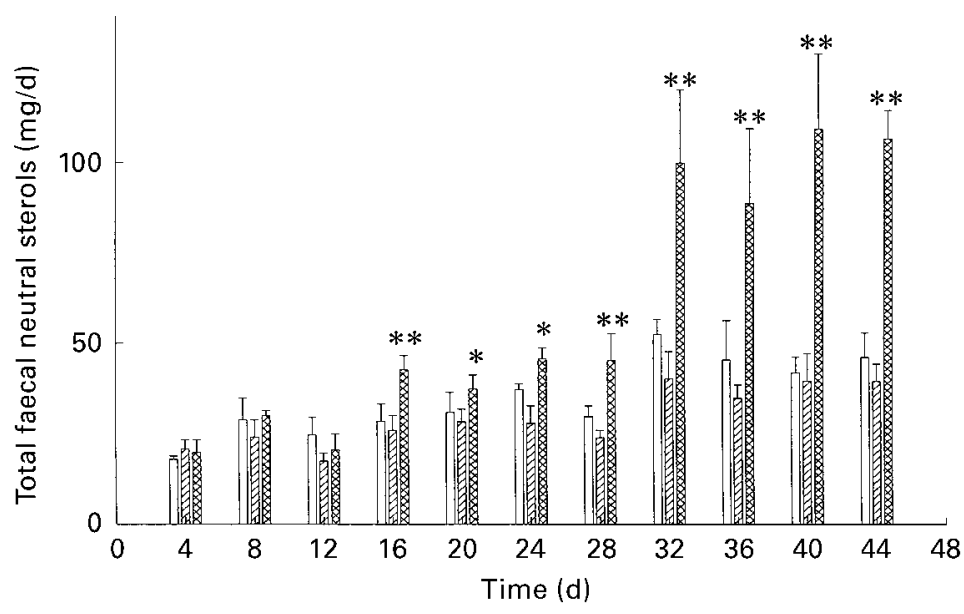

Fig. 2. Effects of conjugated linoleic acids (CLA) and linoleic acid (LA) on faecal output of total neutral sterols in hamsters. For details of the diets see Table 1, and for procedures see p. 936. Values are means for 10-12 hamsters per group with standard deviations represented by vertical bars. $\square$, control; $\mathbb{2}$, linoleic acid-supplemented, $\otimes$, conjugated linoleic acids-supplemented group. Mean values were significantly different from those of the control group: ${ }^{\star} P<$ $0.05,{ }^{* *} P<0.01$

CLA in adipose tissue at the present time. However, CLA supplementation appeared to reduce the adipose tissue fat pads although it was not significant when compared with the control and LA-supplemented groups (Table 3). Similar observations were also made in the studies of Belury \& Kempa-Steczko (1997), DeLany et al. (1999) and Park et al. (1999). It is possible that CLA may reduce the fat deposition and increase lipolysis in adipocytes coupled with enhanced fatty acid oxidation in both muscle cells and adipocytes as described previously in mice by Park et al. (1997). Therefore, the level of cholesterol per unit mass increased as the total adipose tissue weight and TG was decreased. The present results clearly suggest that CLA may cause 'redistribution' of cholesterol between serum and tissues with a lower level of hepatic cholesterol but a higher level of adipose tissue cholesterol.

One of the other possible mechanisms by which dietary CLA decreased serum cholesterol was explored in the present study. Dietary CLA was associated with increased faecal excretion of neutral sterols. Some of neutral sterols are the products of bacterial modification of cholesterol in large intestine (Kellog, 1974). To the best of our knowledge, the effect of dietary CLA on the faecal excretion of sterols has not previously been reported. Whereas ACAT functions mainly to esterify cholesterol and store it as cholesteryl ester, it may be involved in the intestinal absorption of cholesterol (Heider et al. 1983; Largis et al. 1989). There is evidence that the majority of dietary

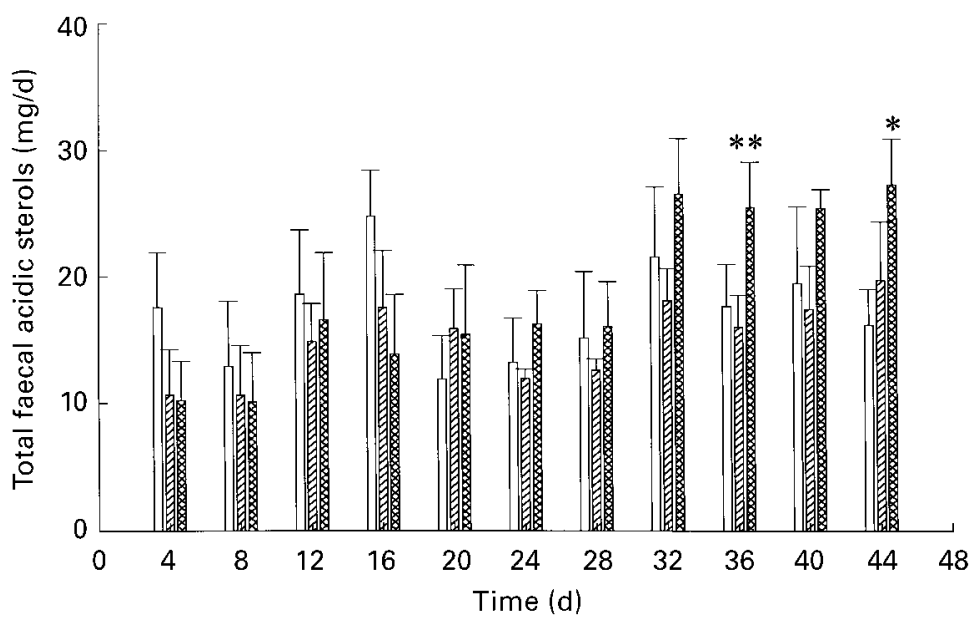

Fig. 3. Effects of conjugated linoleic acids (CLA) and linoleic acid (LA) on faecal output of total acidic sterols in hamsters. For details of the diets see Table 1, and for procedures see p. 936. Values are means for 10-12 hamsters per group, with standard deviations represented by vertical bars. $\square$, control, 四, linoleic acid-supplemented, $\otimes$, conjugated linoleic acids-supplemented group. Mean values were significantly different from those of the control group: ${ }^{\star} P<$ $0.05,{ }^{\star \star} P<0.01$ 
cholesterol is esterified before it is assembled in the chylomicron and secreted into the lymphatic system (Wrenn et al. 1995). We hypothesize that dietary CLA may interfere with the absorption of cholesterol by inhibiting the ACAT activity. In fact, the present study clearly showed that the intestinal ACAT was downregulated by CLA supplementation. This was in agreement with the observation that dietary CLA increased only the faecal excretion of neutral sterols, but it had no or little effect on faecal acidic sterols (Figs 2 and 3). It is known that a high-cholesterol and -lard diet would produce an increase in both liver cholesterol and TG of hamsters (Sessions \& Salter, 1994). Thus, if CLA inhibits cholesterol absorption, CLA supplementation will lead to a decrease in both serum TC and TG, and hepatic cholesterol. In addition, dietary supplementation exhibited neutral effect on HMG-CoA reductase. The reduction in serum cholesterol by dietary supplementation is therefore not associated with the inhibition of hepatic HMG-CoA reductase activity, but is most likely to be mediated, at least in part, by its inhibitory effect on cholesterol absorption via the downregulation of intestinal ACAT activity.

It remains unclear whether dietary CLA reduces serum lipids in man. To the best of our knowledge, there has been no study to date that examines the hypolipidaemic activity of dietary CLA in human subjects. There were, however, only four animal studies to date which examined the hypolipidaemic potency of CLA. When rabbits were given a high-cholesterol diet and $0.5 \mathrm{~g} \mathrm{CLA} / \mathrm{d}$, both serum TC and TG concentrations were significantly lower than the control group (Lee et al. 1994). Examination of the aortas of CLA-fed rabbits showed less atherosclerosis. When hamsters were used as an animal model and fed a highcholesterol diet with three levels of CLA $(0 \cdot 06,0 \cdot 11$ and $1.1 \%$ energy), they had significantly reduced levels of plasma TC, non-HDL-cholesterol and TG as compared with the control hamsters (Nicolosi et al. 1997). Morphometric analysis of aortas revealed less early atherosclerosis in the CLA-fed hamsters compared with the control. In contrast, another study in hamsters fed a high-cholesterol diet containing $6 \mathrm{~g} \mathrm{CLA} / \mathrm{kg}$ diet showed that CLA decreased total cholesterol at week 4 but it had no effect at week 8 (de Deckere et al. 1999). When mice were fed a high-cholesterol diet supplemented with $5 \mathrm{~g} \mathrm{CLA} / \mathrm{kg}$ diet, they developed a significantly higher serum HDL-cholesterol:TC ratio and a significantly lower serum TG concentration than the control (Munday et al. 1999). However, the CLA-fed mice showed an increased development of aortic fatty streak. The present study is the first to explore the mechanism by which dietary CLA favourably alters serum lipoprotein profile. The results demonstrated that CLA decreased intestinal ACAT activity and thereby increased the neutral sterol excretion in hamsters. Although most animal experiments have demonstrated the beneficial effect of dietary CLA, it is premature to extrapolate the data to man because the doses of CLA used in the animal studies, including the present study, would be difficult to achieve by human subjects. It should be pointed out that meat and dairy products contain a certain amount of CLA but they are also rich in saturated fatty acids.

\section{Acknowledgements}

We thank Mr Asgeir Sæbø of Natural Lipids Ltd, AS, Hovdebygda, Norway for supplying CLA in the present study.

\section{References}

Belury MA \& Kempa-Steczko A (1997) Conjugated linoleic acid modulates hepatic lipid composition in mice. Lipids 32, 199204.

Cawood P, Wichens DG, Iversen SA, Braganza JM \& Dormandy TL (1983) The nature of diene conjugation in human serum, bile and duodenal juice. FEBS Letters 162, 239243.

Chan PT, Fong WP, Cheung YL, Huang Y, Ho WKK \& Chen ZY (1999) Jasmine green tea epicatechins are hypolipidemic in hamsters (Mesocricetus auratus) fed a high-fat diet. Journal of Nutrition 129, 1094-1101.

Chen ZY, Chan PT, Kwan KY \& Zhang A (1997) Reassessment of the antioxidant activity of conjugated linoleic acids. Journal of American Oil Chemists' Society 74, 749-753.

Chin SF, Liu W, Storkson JM, Ha YL \& Pariza MW (1992) Dietary sources of conjugated dienoic isomers of linoleic acid, a newly recognized class of anticarcinogens. Journal of Food Composition and Analysis 5, 185-197.

de Deckere EAM, van Amelsvoort JMM, McNeill GP \& Jones P (1999) Effects of conjugated linoleic acid (CLA) isomers on lipid levels and peroxisome proliferation in the hamster. British Journal of Nutrition 82, 309-317.

DeLany JP, Blohm F, Trutt AA, Scimeca JA \& West DB (1999) Conjugated linoleic acid rapidly reduces body fat content in mice without affecting energy intake. American Journal of Physiology 276, R1172-R1179.

Erickson SK, Cooper AD, Matsui SM \& Gould RG (1977) 7Ketocholesterol: its effects on hepatic cholesterogenesis and its hepatic metabolism in vivo and in vitro. Journal of Biological Chemistry 252, 5186-5193.

Grundy SM (1986) Cholesterol and coronary heart disease: A new era. Journal of American Medical Association 256, 2849-2858.

Grundy SM \& Denke MA (1990) Dietary influences on serum lipids and lipoproteins. Journal of Lipid Research 31, 11491172.

Ha YL, Grimm NK \& Pariza MW (1989) Newly recognized anticarcinogenic fatty acids: identification and quantification in natural and processed cheeses. Journal of Agricultural and Food Chemistry 37, 75-81.

Heider JG, Pickens GE \& Kelly LA (1983) Role of acyl CoA: cholesterol acyltransferase in cholesterol absorption and its inhibition by 57-118 in the rabbit. Journal of Lipid Research 24, 1127-1134.

Helgerud P, Saarem K \& Norum KR (1981) Acyl-CoA: cholesterol acyltransferase in human small intestine: its activity and some properties of the enzymic reaction. Journal of Lipid Research 22, 271-277.

Heller RA \& Strewsbury MA (1976) 3-Hydroxy-3-methylglutaryl coenzyme A reductase from rat liver. Its purification, properties and immunochemical study. Journal of Biological Chemistry 251, 3815-3822.

Hughes PE, Hunter WJ \& Tove SB (1982) Biohydrogenation of unsaturated fatty acids: purification and properties of cis-9, trans-11 octodecadienoic acid reductase. Journal of Biological Chemistry 257, 3643-3649.

Iversen SA, Cawood P, Madigan MJ, Lawson AM \& Dormandy TL (1985) Identification of a diene conjugated 
component of human lipid as octadeca-9,11-dienoic acid. FEBS Letters 171, 320-324.

Kellog TF (1974) Steroid balance and tissue cholesterol accumulation in germfree and conventional rats fed diets containing saturated and polyunsaturated fats. Journal of Lipid Research 15, 574-579.

Kepler CR \& Tove SB (1967) Biohydrogenation of unsaturated fatty acids. Journal of Biological Chemistry 242, 5606-5612.

Largis EE, Wang CH, De Vries VG \& Schaffer SA (1989) CL 277, 082: a novel inhibitor of ACAT-catalyzed cholesterol esterification and cholesterol absorption. Journal of Lipid Research 30, 681-690.

Lee KN, Kritchevsky D \& Pariza MW (1994) Conjugated linoleic acids and atherosclerosis in rabbits. Atherosclerosis 108, 1925 .

Lehmann R, Bhargava AS \& Günzel P (1993) Serum lipoprotein in rats, dogs and monkeys, including method comparison and influence of menstrual cycle in monkeys. European Journal of Clinical Chemistry and Clinical Biochemistry 31, 633-637.

Munday JS, Thompson KG \& James KA (1999) Dietary conjugated linoleic acids promote fatty streak formations in the C57BL/6 mouse atherosclerosis model. British Journal of Nutrition 81, 251-255.

Murakami S, Araki H, Otomo S, Nara Y \& Yamori Y (1995) Effect of HL-004, a novel ACAT inhibitor, on cholesterol accumulation and removal in cultured smooth muscle cells from stroke prone spontaneously hypertensive rats (SHRSP). Life Science 56, 509-520.

Neaton JD, Kuller LH, Wentworth D \& Borhani NO (1984) Total and cardiovascular mortality in relation to cigarette smoking, serum cholesterol concentration and diastolic blood pressure among black and white males followed up for five years. American Heart Journal 108, 759-769.

Nicolosi RJ, Rogers EJ, Kritchevsky D, Scimeca JA \& Huth PJ (1997) Dietary conjugated linoleic acid reduces plasma lipoproteins and early aortic atherosclerosis in hypercholesterolemic hamsters. Artery 22, 266-277.
Nistor A, Bulla A, Filip DA \& Radu A (1987) The hypolipidemic hamsters as a model of experimental atherosclerosis. Atherosclerosis 68, 159-165.

Park Y, Albright KL, Liu W, Storkson JM, Cook ME \& Pariza MW (1997) Effect of conjugated linoleic acid on body composition in mice. Lipids 32, 853-858.

Park Y, Albright KL, Storkson JM, Cook ME \& Pariza MW (1999) Changes in body composition in mice during feeding and withdrawal of conjugated linoleic acid. Lipids 34, 243-248.

Sanders TA \& Sandaradura S (1992) The cholesterol-raising effect of coffee in the Syrian hamster. British Journal of Nutrition 68, 431-434.

Sehat N, Yurawecz MP, Roach JAG, Mossoba MM, Kramer JKG \& Ku Y (1998) Silver-ion high-performance liquid chromatographic separation and identification of conjugated linoleic acid isomers. Lipids 33, 217-221.

Sessions VA \& Salter AM (1994) The effect of different dietary fats and cholesterol on serum lipoprotein concentrations in hamsters. Biochimica et Biophysica Acta 1211, 207-214.

Shapiro DJ, Imblum RL \& Rodwell VW (1969) Thin-layer chromatographic assay for HMG-CoA reductase and mevalonic acid. Analytical Biochemistry 31, 383-390.

Sugiyama Y, Odaka H, Itokawa S, Ishikawa E, Tomari Y \& Ikeda H (1995) TMP-153, a novel ACAT inhibitor, lowers plasma cholesterol through its hepatic action in Golden hamsters. Atherosclerosis 118, 145-151.

Vegas GL, Groszek E, Wolf R \& Grundy SM (1982) Influence of polyunsaturated fats on the composition of plasma lipoproteins and apolipoproteins. Journal of Lipid Research 23, 811-822.

Wrenn SM, Parks JS Jr, Immermann FW \& Rudel LL (1995) ACAT inhibitors CL283,546 and CL283,796 reduce LDL cholesterol without affecting cholesterol absorption in African green monkeys. Journal of Lipid Research 36, 1199-1210.

Yotsumoto H, Hara E, Naka S, Adlof RO, Emken EA \& Yanagita T (1999) Trans-10, cis-12-linoleic acid reduces apolipoprotein B secretion in HepG2 cells. Food Research International 31, 403-409. 